University of Nebraska - Lincoln

DigitalCommons@University of Nebraska - Lincoln

Nebraska Cooperative Fish \& Wildlife Research Nebraska Cooperative Fish \& Wildlife Research Unit -- Staff Publications

2000

\title{
Shrinkage of Inland Silverside Larvae Preserved in Ethanol and Formalin
}

\author{
Mandy K. Cunningham \\ Texas Tech University \\ William F. Granberry \\ Texas Tech University \\ Kevin L. Pope \\ University of Nebraska-Lincoln, kpope2@unl.edu
}

Follow this and additional works at: https://digitalcommons.unl.edu/ncfwrustaff

Part of the Other Environmental Sciences Commons

\footnotetext{
Cunningham, Mandy K.; Granberry, William F.; and Pope, Kevin L., "Shrinkage of Inland Silverside Larvae Preserved in Ethanol and Formalin" (2000). Nebraska Cooperative Fish \& Wildlife Research Unit -- Staff Publications. 14.

https://digitalcommons.unl.edu/ncfwrustaff/14
}

This Article is brought to you for free and open access by the Nebraska Cooperative Fish \& Wildlife Research Unit at DigitalCommons@University of Nebraska - Lincoln. It has been accepted for inclusion in Nebraska Cooperative Fish \& Wildlife Research Unit -- Staff Publications by an authorized administrator of DigitalCommons@University of Nebraska - Lincoln. 


\title{
Shrinkage of Inland Silverside Larvae Preserved in Ethanol and Formalin
}

\author{
Mandy K. Cunningham, William F. Granberry, JR., \\ AND KEVIN L. POPE* \\ Department of Range, Wildlife, and Fisheries Management, \\ Texas Tech University, Lubbock, Texas 79409-2125, USA
}

\begin{abstract}
Length measurements of preserved larval fish are necessary in many types of larval fish surveys. If the fixative causes significant shrinkage, then the preserved lengths cannot be used to indicate accurate live lengths. The objective of this study was to determine how preservation in two different concentrations of formalin and ethanol affects the total length of larval inland silversides Menidia beryllina. Larvae were measured (nearest $0.1 \mathrm{~mm}$ ) and individually fixed in one of four fixative treatments (80\% ethanol, $100 \%$ ethanol, 5\% buffered formalin, and $10 \%$ buffered formalin). Fish were remeasured (nearest $0.1 \mathrm{~mm}$ ) at $15 \mathrm{~min} ; 4 \mathrm{~h}$; and $1,7,14$, and $21 \mathrm{~d}$ after preservation. Most shrinkage occurred within the first day after preservation in all four fixatives. Initial length was positively correlated with absolute shrinkage, but percent shrinkage was not affected by initial length. We found no difference in percent shrinkage between the $80 \%$ and $100 \%$ ethanol concentrations. The $10 \%$ buffered formalin caused more percent shrinkage than 5\% buffered formalin. Furthermore, ethanol ( $80 \%$ and $100 \%$ combined) caused greater percent shrinkage than either $5 \%$ or $10 \%$ buffered formalin.
\end{abstract}

Accurate length measurements are necessary in many types of larval fish surveys to determine factors such as age, growth, or size-selective mortality. When a large number of fish are collected in the field, it is often necessary to preserve them so they can be analyzed later. If the fixative causes significant shrinkage, then preserved lengths cannot be used to indicate accurate live lengths.

Past studies have documented that shrinkage of larval fishes preserved in formalin varies among species. For example, Pacific herring Clupea pallasi larvae preserved in 20-30\% formalin shrank about 3\% (Hay 1982), and silver hake Merluccius bilinearis preserved in $4 \%$ formalin shrank $4.3 \%$ (Fowler and Smith 1983). However, southern flounder Paralichthys lethostigma had no consistent change in length when preserved in $4 \%$ formalin (Tucker and Chester 1984). Although most studies found at least some shrinkage of larval fish

* Corresponding author: kevin.pope@ttu.edu

Received November 12, 1999; accepted February 14, 2000 preserved in formalin, larval Mozambique mouthbrooder Sarotherodon mossambicus (=Mozambique tilapia Tilapia mossambica) actually increased $1.7 \%$ in length when preserved in $10 \%$ formalin (Billy 1982).

Different shrinkage rates between species also occurred with alcohol preservation. Fisher et al. (1998) found $12.3 \%$ shrinkage of yellow perch Perca flavescens, but no difference between ethanol concentrations of 50, 80, 95, and $100 \%$. Silver hake larvae shrank $7 \%$ when preserved in $95 \%$ ethanol (Fowler and Smith 1983), and larval sea bass Dicentrarchus labrax (=European bass Morone labrax) shrank $4 \%$ in $70 \%$ ethanol (Jennings 1991). Contradicting most other studies, larval northern anchovy Engraulis mordax did not shrink when preserved in $80 \%$ ethanol, but shrank $8 \%$ when preserved in 5\% formalin (Theilacker 1980). Because different amounts of shrinkage in formalin and ethanol have been reported for different species, assessments of shrinkage caused by preservation must be species-specific.

Our objective was to determine how preservation in two different concentrations of formalin and ethanol affects total length of larval inland silversides Menidia beryllina. We examined length change relative to initial length and compared the effects of the two fixative types.

\section{Methods}

Larval inland silversides were collected with a 500- $\mu \mathrm{m}$-mesh icthyoplankton trawl from Buffalo Springs Lake, a eutrophic west Texas reservoir. To ensure a wide range of initial lengths, fish were collected on $2 \mathrm{~d}$ a week apart. Live fish were transported to the laboratory. An $80 \%$ ethanol fixative was prepared by diluting ethanol (190 proof undenatured) with reverse-osmosis-filtered (RO) water. A $5 \%$ buffered formalin fixative was prepared by diluting $10 \%$ buffered formalin $(40 \mathrm{~mL}$ formaldehyde, $960 \mathrm{~mL}$ RO water, $4.0 \mathrm{~g}$ sodium acid phosphate [monobasic], and $6.5 \mathrm{~g}$ anhydrous sodium phosphate) with RO water (1:1). We used 75 fish for each fixative (80\% ethanol, $100 \%$ ethanol, 


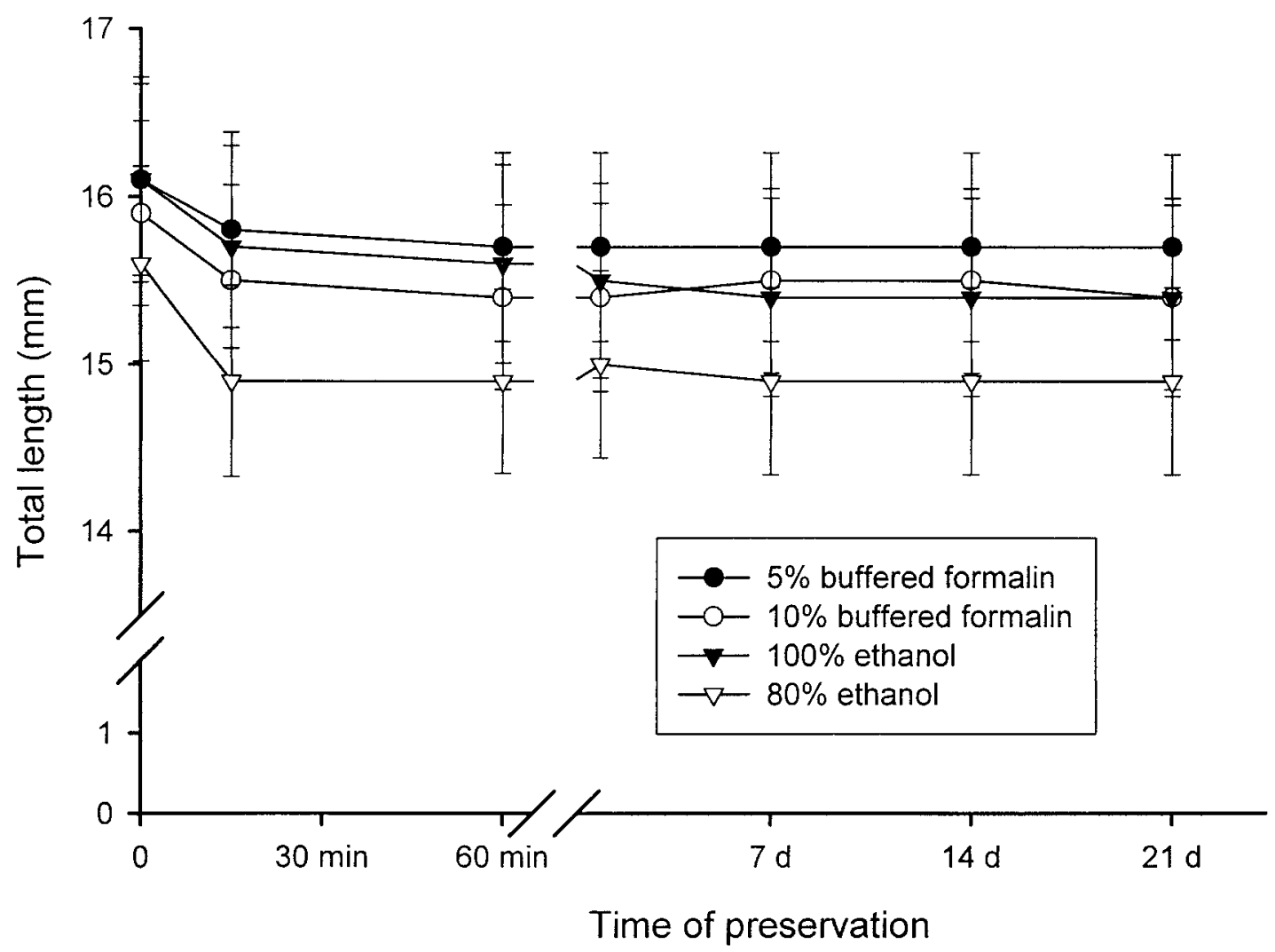

FIGURE 1.-Mean $( \pm$ SE) total lengths of larval inland silversides preserved in two concentrations of ethanol and two concentrations of buffered formalin. Measurements were completed at 0 min (initial length); $15 \mathrm{~min} ; 1 \mathrm{~h}$; and $1,7,14$, and $21 \mathrm{~d}$ after preservation.

$5 \%$ buffered formalin, and $10 \%$ buffered formalin) with approximately $5 \mathrm{~mL}$ of fixative for each fish (300 total larvae). Each fish was euthanatized with tricaine methanesulfonate (MS-222) and immediately measured (nearest $0.1 \mathrm{~mm}$ ) with an ocular micrometer on a dissecting microscope to obtain initial total length (nearest $0.1 \mathrm{~mm}$ ). Individual fish were randomly placed into individual vials containing the appropriate fixative. Fish were remeasured at $15 \mathrm{~min} ; 4 \mathrm{~h}$; and $1,7,14$, and $21 \mathrm{~d}$ after preservation.
Analysis of variance (ANOVA) within fixatives was used to test for differences in initial and preserved lengths. Pearson's product-moment correlation was used to assess relations of initial length to absolute and percent shrinkage. An ANOVA was used to test for differences in percent shrinkage among the four fixatives.

\section{Results and Discussion}

Initial length of preserved larval inland silversides ranged from 6.3 to $29.7 \mathrm{~mm}$ (Table 1).

TABLE 1.-Range of initial total lengths and mean ( \pm SE) percent shrinkage of larval inland silversides over $21 \mathrm{~d}$ of preservation in two concentrations of ethanol and two concentrations of buffered formalin.

\begin{tabular}{|c|c|c|c|c|c|c|}
\hline \multirow[b]{2}{*}{ Fixative } & \multirow{2}{*}{$\begin{array}{l}\text { Range of } \\
\text { initial total } \\
\text { lengths } \\
(\mathrm{mm})\end{array}$} & \multicolumn{5}{|c|}{ Mean shrinkage $(\%)$ after preservation for } \\
\hline & & $4 \mathrm{~h}$ & $1 \mathrm{~d}$ & $7 \mathrm{~d}$ & $14 \mathrm{~d}$ & $21 \mathrm{~d}$ \\
\hline $80 \%$ ethanol & $6.3-26.7$ & $3.8 \pm 0.3$ & $3.6 \pm 0.3$ & $3.8 \pm 0.3$ & $3.7 \pm 0.3$ & $3.9 \pm 0.4$ \\
\hline $100 \%$ ethanol & $8.4-29.7$ & $3.4 \pm 0.4$ & $3.9 \pm 0.3$ & $4.1 \pm 0.3$ & $4.5 \pm 0.5$ & $4.1 \pm 0.3$ \\
\hline $5 \%$ buffered formalin & $7.8-27.9$ & $2.4 \pm 0.3$ & $2.5 \pm 0.3$ & $2.3 \pm 0.3$ & $2.3 \pm 0.2$ & $2.2 \pm 0.2$ \\
\hline $10 \%$ buffered formalin & $8.6-27.0$ & $3.6 \pm 0.4$ & $4.3 \pm 0.4$ & $3.2 \pm 0.3$ & $3.2 \pm 0.3$ & $3.2 \pm 0.3$ \\
\hline
\end{tabular}


Lengths of inland silverside larvae differed between the initial and 21-d measurements for all four fixatives: $80 \%$ ethanol $(F=8,216$, df $=1$, $73, P=0.0001), 100 \%$ ethanol $(F=13,486, \mathrm{df}$ $=1,73, P=0.0001), 5 \%$ buffered formalin $(F=$ $22,380$, df $=1,73, P=0.0001)$, and $10 \%$ buffered formalin $(F=15,211$, df $=1,71, P=0.0001)$. Mean percent shrinkage after $21 \mathrm{~d}$ was $3.9 \%(80 \%$ ethanol), $4.1 \%$ ( $100 \%$ ethanol), $2.2 \%$ (5\% buffered formalin), and $3.2 \%$ (10\% buffered formalin). Most shrinkage occurred within the first day (Figure 1). Even though initial length was positively correlated (80\% ethanol: $r=0.33, P=0.004$; 100\% ethanol: $r=0.48, P=0.0001 ; 5 \%$ buffered formalin: $r=0.40, P=0.0004 ; 10 \%$ buffered formalin: $r=0.26, P=0.02$ ) with absolute shrinkage, percent shrinkage was not affected by initial length (all $P>0.4$ ).

Percent shrinkage differed among the four fixatives $(F=8.91, \mathrm{df}=3,294, P=0.0001)$. There was no difference in percent shrinkage between the two ethanol treatments $(F=0.18$, df $=1,148$, $P=0.67)$. However, the $10 \%$ buffered formalin caused more percent shrinkage than the $5 \%$ buffered formalin $(F=7.03$, df $=1,146, P=0.009)$. Furthermore, ethanol $(80 \%$ and $100 \%$ combined results) caused greater percent shrinkage than $5 \%$ buffered formalin $(F=25.3$, df $=1,223, P=$ $0.0001)$ and $10 \%$ buffered formalin $(F=5.01, \mathrm{df}$ $=1,221, P=0.026$ ).

As expected, greater shrinkage occurred in ethanol than in buffered formalin, but the difference between fixatives was not as great as that reported for other fish species (e.g., Fowler and Smith 1983; Kruse and Dalley 1990; Fisher et al. 1998). We also found no correlation between initial length and percent shrinkage, whereas other studies have documented increased percent shrinkage in shorter larvae (e.g., Hay 1982; Fowler and Smith 1983; Morkert and Bergstedt 1990).

When possible, total length of preserved specimens should be adjusted to account for length reductions caused by preservation. Formalin should be used in place of ethanol to preserve larval inland silversides when minimal shrinkage is important. However, ethanol should be used to preserve larval inland silversides if otolith analysis is planned because of the degenerative effects of formalin on calcified structures (Essig and Cole 1986).

\section{Acknowledgments}

We thank the community of Buffalo Springs Lake for lake access. Houston Livestock Show and Rodeo provided partial funding for this project. Reynaldo Patiño, Calub Shavlik, and Gene Wilde provided comments on an earlier draft of this manuscript. This is contribution T-9-847 of the College of Agricultural Sciences and Natural Resources, Texas Tech University, Lubbock.

\section{References}

Billy, A. J. 1982. The effects of formalin and isopropyl alcohol on length and weight measurements of Sarotherodon mossambicus Trewavas. Journal of Fish Biology 21:107-112.

Essig, R. J., and C. F. Cole. 1986. Methods of estimating larval fish mortality from daily increments of otoliths. Transactions of the American Fisheries Society 115:34-40.

Fisher, S. J., M. R. Anderson, and D. W. Willis. 1998. Total length reduction in preserved yellow perch larvae. North American Journal of Fisheries Management 18:739-742.

Fowler, G. M., and S. J. Smith. 1983. Length changes in silver hake (Merluccius bilinearis) larvae: effects of formalin, ethanol, and freezing. Canadian Journal of Fisheries and Aquatic Sciences 40:866-870.

Hay, D. E. 1982. Fixation shrinkage of herring larvae: effects of salinity, formalin concentration, and other factors. Canadian Journal of Fisheries and Aquatic Sciences 39:1138-1143.

Jennings, S. 1991. The effects of capture, net retention and preservation upon lengths of larval and juvenile bass, Dicentrarchus labrax (L.). Journal of Fish Biology 38:349-357.

Kruse, G. H., and E. L. Dalley. 1990. Length changes in capelin, Mallotus villosus (Muller), larvae due to preservation in formalin and anhydrous alcohol. Journal of Fish Biology 36:619-621.

Morkert, S. B., and R. A. Bergstedt. 1990. Shrinkage of sea lamprey larvae preserved in formalin. North American Journal of Fisheries Management 10: 484-486.

Theilacker, G. H. 1980. Changes in body measurements of larval northern anchovy, Engraulis mordax, and other fishes due to handling and preservation. Fishery Bulletin 78:685-692.

Tucker, J. W., Jr., and A. J. Chester. 1984. Effects of salinity, formalin concentration and buffer on quality of preservation of southern flounder (Paralichthys lethostigma) larvae. Copeia 1984:981-988. 